\section{Rysa, dukt, odcisk (nie)obecności. O spektrologiach Zagłady}

\section{Aleksandra Ubertowska}

TEKSTY DRUGIE 2016, NR 2, S. 102-121

DOI: 10.18318/td.2016.2.7

Przyszłość jest pamięcią umartych. ${ }^{1}$ Jacques Derrida

Z tytu z hukiem trzasnęty ciężkie drzwi do starej synagogi,jakby wszystkie duchy wyleciałyzobaczyć, co się stato. ${ }^{2}$

Zygmunt Miłoszewski

\section{$\mathbf{R}$} ozprawy 'widmoontologiczne', poświęcone literaturze posttraumatycznej, a zwłaszcza piśmiennictwu o Zagładzie, rozwijają najczęściej wzorzec myślenia, który narzuca się w sposób dość oczywisty - jest to trop interpretacyjny, ukierunkowany na opis żydowskich duchów, zjaw, „żywych umarłych”, powracających z zaświatów, by upomnieć się o należyty pochówek, o domknięcie symbolicznej „kryptycznej” syntagmy, zainicjowanej pod murem warszawskiego getta, w Jedwabnem,

1 J. Derrida Marx' Gespenster, przeł. S. Luedemann, Suhrkamp, Frankfurt am Main 2004, s. 58.

2 Z. Miłoszewski Ziarno prawdy, W.A.B., Warszawa 2014, s. 17.
(A)

Artykułniniejszy został napisany w ramach realizacji projektu badawczego pt. „Ekopoetyki historycznych katastrofi konfliktów w literaturze polskiej XX iXXI wieku. Perspektywa porównawcza", finansowanego przez Narodowy Program Rozwoju Humanistyki. Numer projektu: $2 \mathrm{aH} 15005683$.

\author{
Aleksandra Uber- \\ towska - literatu- \\ roznawca, profesor \\ Uniwersytetu \\ Gdańskiego, obszary \\ jej zainteresowań ba- \\ dawczych to literatu- \\ ra Holocaustu, gender \\ studies, problema- \\ tyka tożsamości, \\ ekokrytyka. Swoje \\ artykuły zamieszczała \\ na łamach „Tekstów \\ Drugich”, „Pamiętnika \\ Literackiego”, ,Ruchu \\ Literackiego", tomów \\ zbiorowych polskich \\ i zagranicznych \\ wydawnictw (m.in. \\ Lexington Books, \\ Peter Lang, Akademie \\ Verlag). Kontakt: \\ ubertowska@wp.pl
}


obozach deportacyjnych w Transnistrii ${ }^{3}$. Ten tryb postępowania uprawomocnia literacka materia badanych tekstów. Spektralnych scenerii, obrazów poetyckich, konwencji określających kondycję świata przedstawionego jest w obszarze piśmiennictwa o Zagładzie bardzo wiele, by przywołać tu - na prawach przypadkowego wyboru - Cienie Kornela Filipowicza i Pensjonat Piotra Pazińskiego, Tamta stronę Bogdana Wojdowskiego i tom opowiadań W.G. Sebalda Die Ausgewanderten [Wyjechali], poezję Nelly Sachs i Jerzego Ficowskiego, wreszcie najnowsze powieści z silnie wyeksponowanym motywem hauntologicznym: Fabrykę muchołapek Andrzeja Barta i Noc żywych Żydów Igora Ostachowicza. Wszystkie te utwory potwierdzają słuszność sądu, wyrażonego przez Colina Davisa, który stwierdził, że „historia Europy może być postrzegana jako nieudana próba pozbycia się swoich własnych duchów. [Jednak my - przyp. A.U.] [...] nie jesteśmy jeszcze gotowi, aby ostatecznie rozstać się z naszymi umarłymi"

Wpływ hauntologii przejawia się jednak również w obszarze krytyki i teorii kultury. Spektralny tryb interpretacji ustanowił niemal odrębną metodologię w obrębie 'holocaust studies', z powodzeniem uprawianą przez przedstawicieli różnych dziedzin badawczych. Wedle tej metody Marianne Hirsch objaśnia istotę estetycznej wrażliwości, sygnowanej formułą 'postmemory', również w wymiarze osobistego doświadczenia, o czym świadczy publikacja głośnej autobiograficznej książki Ghosts of Home. Afterlife of Czernowitz in Jewish Memory ${ }^{5}$. Rozprawa ta wydaje się modelowym zastosowaniem hauntologii w badaniach nad literackim zapisem postpamięci, zwłaszcza w odniesieniu do przestrzeni jako fundamentu operacji memorialnych. W Ghosts of Home zasada ta dominuje - na realną topografię współczesnego ukraińskiego miasta

3 Zob. P. Czapliński Katastrofa wsteczna, "Poznańskie Studia Polonistyczne” Seria Literacka 2015 nr 25 (45). Autor wprowadza w swoim artykule koncepcję "katastrofy wstecznej" na oznaczenie miejsca zagłady Żydów w kulturze polskiej, tak wykładając znaczenie tej formuły: "Czy jest możliwy pożar, który wybuchł dawno temu, ale dopiero teraz zaczyna pochłaniać budynki? Albo trzęsienie ziemi, które wydarzyło się niegdyś, ale niszczy dzisiejsze miasto? Tak, sądzę, że właśnie taki pożar i takie trzęsienie ziemi są możliwe - niegdyś niezauważone, więc nierzeczywiste, a rzeczywiste dopiero wtedy, gdy wreszcie zauważone. To właśnie katastrofa wsteczna. Świadkowie nie widzieli, gdy trwała, nie rozpoznali jej istoty, nie wymyślili środków zapobiegawczych na przyszłość. Kiedy po jakimś czasie ich potomkowie odzyskują zdolność widzenia i rozumienia, kiedy opracowują środki zaradcze, katastrofa, która już kiedyś nastąpiła, zaczyna dziać się powtórnie - rozprzestrzeniając się we wszystkich kierunkach" (s. 37).

C. Davis Powrót umarłych, przeł. A. Marzec, "Czas Kultury” 2013 nr 2, s. 28.

5 M. Hirsch, L. Spitzer Ghosts od Home. The Afterlife of Czernowitz in /ewish Memory, University of California Press, Berkeley-Los Angeles 2010. 
projektowane są „wirtualne” mapy niegdysiejszych ulic i placów, bohaterowie narracji Hirsch żyją w wielu wymiarach czasowych, przekraczając granice umownych realności cząstkowych retrospektywnych opowieści. Metoda uprawiana przez Marianne Hirsch jest stosowana w wielu odmianach i zróżnicowanym zakresie. Spektralną analizę uprawia Jakub Momro, przeprowadzając w Widmontologiach nowoczesności interpretację powieści Elfriede Jelinek pt. Dzieci umartych ${ }^{\mathbf{6}}$, podobnie postępuje Sylwia Karolak w krótkim przeglądzie literackich widm opublikowanym w monograficznym numerze „Czasu Kultury", a także Elżbieta Janicka w autorskiej formule fotoeseju, poświęconego polityce pamięci ujawniającej się na terenach dawnego getta (Festung War$\left.s c h a u^{8}\right)$. Również James E. Young w swojej książce o ponowoczesnej sztuce o Zagładzie posługuje się terminami spektralnymi: „obrazy z drugiej ręki”, 'hologramy', post-obrazy (w niemieckim przekładzie jego książki użyto bardziej sugestywnego słowa na określenie tych przedstawień - „Nach-Bilder"9). W ujęciu Younga spektralność jest niemal tożsama z postmodernizmem, sztuką, która przychodzi „po” i pasożytuje na nowoczesnej formule świadectwa (lub, przeciwnie, awangardowego eksperymentu).

Powstaje jednak wrażenie, że mówienie o żydowskich upiorach, zjawach, rozumianych jako personalne ‘dublety' żydowskich mieszkańców, którzy nawiedzają współczesnych mieszkańców Zamościa, Śródborowa, warszawskiego Muranowa, o widmowych przestrzeniach żydowskich miast jest konceptem nieco wyeksploatowanym interpretacyjnie, pozostawiającym badaczowi, zwłaszcza badaczowi literatury, niewielkie pole manewru. Przy czym zaznacza się tu znacząca rozbieżność. „Żydowskie widma” wydają się dobrze osadzone w planie świata przedstawionego powieści postmemorialnych Szewca, Pazińskiego, Ostachowicza, jednak próba interpretacji (osadzenia w dyskursie) tych figur ujawnia ich intelektualną jednostronność i uwikłanie w dwuznaczne aporie. Widma, zjawy, żydowskie zombi wydają się figurami tyleż przerażającymi, co mieszczącymi się w konwencji ludycznej, z lekka perwersyjnej rozrywki - doznanie „niesamowitego” jest tu oddalone, zapośredniczone, ujęte w ramę uspokajającej konwencji. Trudno oprzeć się wrażeniu,

6 J. Momro Widmontologie nowoczesności. Genezy, Wydawnictwo IBL PAN, Warszawa 2015.

7 S. Karolak Widma (z) Zagłady , "Czas Kultury” 2013 nr 2.

8 E. Janicka Festung Warschau. Raport z oblężonego miasta, Wydawnictwo Krytyki Politycznej, Warszawa 2012.

9 J.E. Young Nach-Bilder des Holocaust in zeitgenössischer Kunst und Architektur, przeł. E. Knörer, Hamburger Edition, Hamburg 2002. 
że to figury epistemologicznie oswojone, estetycznie zaś dwuznacznie ocierające się o kicz.

\section{Anachronie widma}

W kontekście tego, co zostało tu powiedziane, uzasadnione wydaje się ponowne przemyślenie podstaw hauntologii Jacques'a Derridy, wyłożonej w późnych książkach francuskiego filozofa: przede wszystkim w Widmach Marksa $^{10}$, a także w $O d u c h u^{11}$ oraz w zbiorze Prawda w malarstwie ${ }^{12}$. Ich relekturze towarzyszyć tu będzie konceptualizacja zmierzająca do odnalezienia w teorii Derridiańskiej pragmatycznych narzędzi, które mogą okazać się pomocne w interpretacji posttraumatycznych tekstów literackich i dzieł sztuki. Autor $O$ Gramatologii jest wszakże ojcem-założycielem teorii spektralnej ${ }^{13}$ jako autor wymienionych dzieł, a także istotnego w tym kontekście (choć nieuwzględnionego przeze mnie) komentarza Fors do eseju Kryptonimie Nicolasa Abrahama i Márii Török ${ }^{14}$. Praca intelektualna poświęcona tym rozprawom potwierdziła słuszność sądu J. Hillisa Millera, który stwierdził, że po śmierci autora Chory trwa nieustający „czas Derridy”"15, jego filozofia bowiem zawiera fundamenty myślowe procesów dziś zachodzących i tych, które widnieją na horyzoncie historii' ${ }^{16}$.

J. Derrida Spectres de Marx: l'État de la dette, le travail du deuil et la nouvelle Internationale, Galilée, Paris 1993. Korzystam z niemieckiego przekładu: Marx' Gespenster. Der Staat der Schuld, die Trauerarbeit und die neue Internationale, przeł. S. Luedemann, Suhrkamp, Frankfurt am Main 2004.

11 J. Derrida O duchu. Heidegger i pytanie, przeł. B. Brzezińska, PWN, Warszawa 2015.

12 J. Derrida Prawda w malarstwie, przeł. M. Kwietniewska, słowo/obraz terytoria, Gdańsk 2003.

13 Zob. J. Castricano Criptomimesis. The Gothic and Jacques Derrida's Ghost Writing, McGill Queens University, Montréal 2001.

14 Krótki, ale inspirujący zarys hauntologii Derridy (aczkolwiek poruszający zupełnie inne zagadnienia niż te w niniejszym artykule) proponuje Andrzej Marzec w artykule Widma, zjawy i nawiedzone teksty - hauntologia Jacquesa Derridy, czyli o pośmiertnym życiu literatury. https:// www.academia.edu/2529603/Widma_zjawy_i_nawiedzone_teksty_hauntologia_Jacquesa_Derridy_czyli_o_po\%C5\%9Bmiertnym_\%C5\%BCyciu_literatury (23.09.2015). Zob. też tego samego autora: Widma, w: tegoż Widmontologia. Teoria filozoficzna i praktyka artystyczna ponowoczesności, Bęc Zmiana, Warszawa 2015.

15 J. Hillis Miller Jak czytać Derridów: indeksowanie 'moi et moi', Der und Der, mnie i mnie, tego i tamtego, przeł. K. Hoffman, "Czas Kultury” 2014 nr 5, s. 7.

16 Por. też C. Gaudin Zamknięcie tradycji filozoficznej: Derrida, eksplorator marginesów, przeł. K. Matuszewski, w: Derridiana, wyb. B. Banasiak, Interesse, Kraków 1994. 
Francuski filozof formułuje we wspomnianych książkach wielce oryginalną koncepcję widma, bardzo odległą od potocznych mniemań na temat jego kondycji. Myśli on o spektralności w polu wyznaczanym przez osie trzech tematów: problemu czasu, serii/seryjności i materialnej formy (widm). Derrida sytuuje więc spektralność w kilku porządkach, które 'zachodzą' na siebie w trybie palimpsestów czy transparentnych okręgów, modyfikujących swoją pozycję w całym dyskursie, dzięki czemu osiąga on efekt samozwrotny - oto refleksja o widmie sama staje się widmowa, znikliwa, niewspółmierna ze sobą.

Najbardziej znaczącą cechą spektralności w ujęciu Derridy jest a n a c h r o n i a, przejawiająca się w znamiennym dla tego zjawiska pomieszaniu czasów, zachodzeniu ich na siebie czy też, inaczej rzecz ujmując, przybierająca formę ontologicznego "zaszczepiania" na sobie różnych wymiarów czasowości. Anachronia określa zasadniczy warunek myśli spektralnej i determinuje rozprawę o niej w punkcie wyjścia już w pierwszych jej zdaniach. Wszakże „widmo komunizmu” z Manifestu komunistycznego Marksa, od którego przywołania rozpoczyna swoją książkę Derrida, przybywa z przyszłości; orzekanie o nim to forma antycypacji, naznaczona lękiem, ale i ekscytacją. Dotyczy to również zapowiedzi lewicowości, lewicowej rewolucji, wyłaniającej się na horyzoncie współczesności" - Marks (a raczej jego „widmo”, którego nadejście zapowiada autor Chory) istnieje jako przyszłość teraźniejszości, żyje w rozwidleniu czasów, których wzajemna relacja jest niestabilna, wahliwa ontologicznie. Kondycja widma zatem - które patrzy na nas, ale nie jest widziane - kumuluje w sobie zasadniczą właściwość bytu: „nierównomierność czasu teraźniejszego z samym sobą"18, która skutkuje zawirowaniem, zmąceniem czasowości. Jej istotę dobrze wyraża Derridiańska formuła „Przyszłość jest pamięcią umarłych"19 , widmo żyje bowiem w wielu wymiarach temporalnych, które w jego kondycji wiążą się, zapętlają. Czas widma zatem to „przyszłość, która przechodzi przez teraźniejszość w stronę przeszłości"20 ${ }^{20}$, to ruch zdobywania samowiedzy przez powtórne rozpoznawanie zdarzeń, tym razem jawiących się jako fantomatyczne. Pochód widm, w którym ludzkość

17 O lewicowym potencjale książki Derridy pisze Bartosz Kuźniarz w artykule Człowieku, w twojej głowie straszy! Derrida o duchach późnego kapitalizmu, "Czas Kultury” 2014 nr 5.

18 J. Derrida Marx'Gespenster..., s. 43.

19 Tamże, s. 58.

20 Tamże, s. 42-43. 
od-poznaje samą siebie, postępuje przez zerwania, niespójności, różnice, cofa się lub przepisuje zdarzenia w nowym kodzie czasowym. Historia natomiast jest według Derridy zalepianiem tych czasowych dysjunkcji.

Spektrologia Derridy sytuuje się więc na antypodach zjawiska, które moglibyśmy nazwać antropomorfizacją zjaw. Przeciwnie, filozof dokonuje radykalnej depersonalizacji widma, mówiąc, że upiór to coś „pomiędzy rzeczą a osobą"21 (inspirując się tu Hamletowskim „the thing"), choć może ono posługiwać się 'personą' jako formą, kostiumem. W innym miejscu Derrida powiada, że widmo sytuuje się między osobą i jej fantazmatem, będąc czymś zdecydowanie nieludzkim (postludzkim?). Autor Chory definiuje spektralność jako „strukturę zanikającego zjawiska"22 , jako projektowanie fantomów na ekran, którego natura również okazuje się fantomatyczna. Ten sposób myślenia z trudem pozwala się pogodzić z konwencją poczciwych upiorów czy zombi, w znacznie większym stopniu wydaje się natomiast zbliżony do metody analizy spektralnej w fizyce, gdzie skład substancji ustala się na podstawie barwnego 'powidoku' jej podgrzanej próbki, lub gdy tropi się istnienie gwiazdy, której już nie ma, na podstawie pozostawionego przez nią świetlnego śladu. Uprawnione wydaje się więc stwierdzenie, że dyskurs spektralny jest dla Derridy instrumentem formułowania radykalnych sądów (post)metafizycznych - autor Widm Marksa zdaje się mówić, że widzimy świat, jaki był lub jaki będzie (a nie jaki „jest” teraz); że to, z czym obcujemy, to "rzeczy byłe” lub „przyszłe”, które pozostawiły zjawiskowe, wieloznaczne, niepokojące ślady.

Mówiąc o widmach w ujęciu Derridiańskim, myślimy zawsze w kategoriach serii, seryjności. Naturalny stan istnienia tego, co spektralne, przyjmuje formę łańcucha widm, zaczepionych o inne (wewnętrzne) widma („Jestem nawiedzony przez siebie samego, który jest nawiedzony przez siebie samego, który..." ${ }^{23}$ - mówi narrator eseju Derridy). Seria to struktura wynikania z siebie kolejnych spektralnych znaczących, dlatego też polem (zjaw)iania się widm jest język - domena podwojeń, brzmieniowych i semantycznych opozycji, graficznych duplikacji, takich jak znaczki cudzysłowu czy wyrażenia przydawkowe, wywołujące efekt mnożenia, dysseminacji pojęć („prawda prawdy”,,sślad śladu”,,widmo widma”). Formy te przywodzą na myśl odbicie lustrzane lub dociekliwe, natarczywe poszukiwanie istoty pojęcia.

Tamże, s. 20

Tamże, s. 142.

Tamże, s. 182. 
Jak powiada filozof, „już sama oscylacja dopełniacza wyraża niepewność 'Unheimlichkeit' rzeczy" ${ }^{24}$, tworząc jego widmowe, czyli w tym kontekście - bardziej istotowe odbicie. Wytwarza ona, niezmiernie pożądaną w Derridiańskiej analizie spektralnej, otchłanność dyskursu o widmie, które dzięki wiecznie odsyłającej strukturze 'mise en abyme' jawi się jako „pusty” negatyw, sobowtór nobliwego (Heglowskiego) ducha ${ }^{25}$.

Językowymi i literackimi ekwiwalentami spektralności są wreszcie, jak powiada Derrida, prze-pisywanie , przekład, zapożyczenia, stylizacje, upodobanie do cytatów. Zdanie, otwierające Widma Marksa jest przecież swoistym 'cytatem cytatu', transpozycją formuły, która była przywoływana wielokrotnie w różnorakich kontekstach, zarówno afirmatywnych, jak i kontestujących, jest zatem zawieszona w sieci odczytań, które zacierają wyrazistość tekstu-źródła, choć zarazem czynią jego istnienie niezbywalnym ${ }^{26}$.

Wreszcie, ostatnim warunkiem zaistnienia widma, wyartykułowanym w Derridiańskiej 'abisalnej”, otchłannej „prawdzie prawdy”, jest m a t e r i a l n o ś ć, która wyraża się najpełniej w obrazach rzeczy zniszczonych, zdeformowanych (a zatem „byłych"). Ich szczególny status wiąże się w faktem, że są one „oddzielone od podmiotu”, zatopione w swojej reistycznej kondycji. Tę właściwość spektralności objaśnia filozof na podstawie interpretacji serii zużytych, porzuconych butów uwiecznionych na obrazach van Gogha. Zużycie, porzucenie sprawiają, że kumulują się w nich najbardziej wyraziste wyznaczniki rzeczowości: porowatość, bezużyteczność, a zarazem jakby „lepkie” wspomnienie niegdysiejszej relacji do człowieka, nostalgiczne odniesienie do tego, kto odcisnął ślad obecności w materialności obuwia. Materialność rzeczy jest niejako parergonem czy kartuszem widma ${ }^{27}$, w sposób mglisty i apojęciowy problematyzującym jego graniczność. Inaczej mówiąc, jest ona suplementem spektralności, wychodzącym poza jego ontologiczne granice, bowiem duch, by zaistnieć, musi wniknąć w swój wytwór, obrać formę materialną. Bez materialnego odcisku czy obrysu dyskurs widma byłby

24 J. Derrida Prawda w malarstwie, s. 436.

25 Por. B. Baran Rozplenienie - istota procesu sensotwórczego, w: tegoż Filozofia „końca filozofii”. Dekonstrukcja Jacquesa Derridy, Spacja, Warszawa 1995.

26 Por. S. Kofman Das Schein, das Spiel, w: tejże Derrida lesen, przeł. M. Buchgeister, Passagen Verlag, Wien 2000.

27 Ciekawych przykładów zastosowania Derridiańskiej kategorii parergonu do analizy dzieła sztuki dostarcza książka Ewy Bobrowskiej Parateoria. Kalifornijska Szkoła z Irvine, Wydawnictwo IBL PAN, Warszawa 2013, s. 48-61. 
niesłyszalny, jak idiomatyczność literatury, która nie została osadzona w porządku instytucji ${ }^{28}$.

Właśnie Prawda w malarstwie wydaje się rozprawą o spektralności najbardziej inspirującą dla badacza reprezentacji Holokaustu. Widma posttraumatyczne w ramach rozwijanych tu rozważań istnieją jako materialne ślady owego „bez" (nieobecności, pustki), jako materialna rysa, odcisk obecności, oddechu, ruchu. Istnieją jako „ból fantomowy”, a ta metafora, użyta niegdyś przez Ruth Gruber w odniesieniu do nieobecności Żydów w Europie Środkowo-Wschodniej ${ }^{29}$, dobrze oddaje niezbywalność ciała i porowatość materii. Taka ich kondycja zarazem lokuje dyskurs metafizyczny nad obecnością widma we wnętrzu chiazmatycznego skrzyżowania kategorii: wklęsły/wypukły, wnętrze/obramowanie, symulakrum/oryginał, przyleganie/oddzielenie (widmo mieści się niejako w centrum ich nieustannej wymiany). Buty van Gogha są przez Derridę rozpatrywane jako alegoria reprezentacji - zachowują walor zapośredniczenia, a zarazem nieusuwalnej materialności, ale są również postrzegane jako najdoskonalsze wcielenie widmologiczności. Filozof powiada wszakże, iż „buty nie są nawiedzane przez duchy, lecz są samym

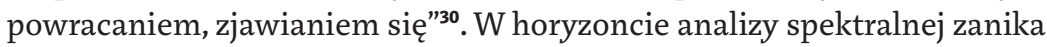
podmiotowość ludzka; moglibyśmy powiedzieć, że 'rozpuszcza' się ona w intensywnej materialności odcisku.

Buty przez swój status rzeczy porzuconej, jak gdyby bezpańskiej, przywołują słowa ze słownika ekonomii, zespolone z zawłaszczeniem, grabieżą, pogromem i masowym rabowaniem majątku ofiar obozów zagłady. Swoistym symbolem tego procederu, symbolem funkcjonującym w kulturze współczesnej w wielu wymiarach, stała się ekspozycja sterty butów w muzeum w Auschwitz, przejmująca i wystawiona na zniszczenie, niepokojąca przez swój nieokreślony status materialnego reliktu i muzealnego eksponatu zarazem. Derrida, polemizując z interpretacjami obrazów van Gogha autorstwa Heideggera i Schapiro stara się ustalić tożsamość „właściciela” butów, przypisać go do określonego miejsca, przestrzeni (wiejskiej lub miejskiej), odgadnąć jego płeć. Nie chodzi tu jednak o ustalenie mieszczańskiego prawa własności,

28 Nawiązuję tu do idei, rozwijanych przez Derridę w wywiadzie Ta dziwna instytucja, zwana literaturq, przeł. M.P. Markowski, „Literatura na Świecie” 1998 nr 11-12. Zob. też M.P. Markowski Efekt inskrypcji. Jacques Derrida i literatura, Homini, Bydgoszcz 1997, s. 200-236. 2004 . 
ale o usytuowanie punktu ogniskowego narracji widmologicznej w samym środku aktu przemocy, wewnątrz gestu masowego zniszczenia, które pozostawiło namacalny, ale i wieloznaczny ślad.

A jednak cała armia duchów domaga się swoich butów. Są to duchy pod bronią albo liczni deportowani, którzy poszukują swoich imion. Jeśli chcecie się udać do tego teatru, prowadzi tam droga afektu: wiekuista pamięć o wywłaszczeniu, ekspropriacji, grabieży. Oraz tony butów stłoczonych w jednym miejscu, pomieszanych i porozdzielanych par. ${ }^{31}$

Dyskurs widma w ujęciu autora O Gramatologii - powtórzmy - rozwija się w polu, wyznaczanym przez filozoficzne zagadnienia 1. anachronii, 2. przekładu, 3. materialności. Jest to pole aktywnie na siebie oddziałujących sił, tworzących ontologiczne zrosty, nieoczywiste przejścia między nimi. Zatem mroczna natura widma to upiorność przemieszczona, przefiltrowana przez rozmaite pryzmaty, wyłaniająca się z nieoczekiwanych niespójności, rozwidleń filozoficznego czy literackiego dyskursu. Widmo w ujęciu autora Glas jest ahistoryczne, nie-ludzkie , a zatem również postludzkie. Jest też złowieszcze, ale w nieoczywisty sposób. Reprezentuje poziom meta-wiedzy epistemologicznej, pełni funkcję podobną do przekroju archeologicznego lub rentgenologicznego zdjęcia, które w jednym błysku prześwietla ukrytą naturę rzeczy. Jednak przenoszona przez niego wiązka informacji istnieje migotliwie, zanika, podszywa się pod inne przekazy czy style mówienia.

\section{Ekspozycja i mimikra}

Ziarno prawdy Zygmunta Miłoszewskiego ${ }^{32}$ w zaskakujący sposób rozwija tropy spektralne, eksponując wątki teatralności, cielesnej makabry i wielopiętrowej mimikry, które maskują swojskość (Unheimlichkeit) zła rozumianego jako zemsta lub/i przemoc pogromowa. Motyw ekspozycji jest tu centralny - dynamika fabuły koncentruje się wokół powtarzalnej sceny widowiskowej ekspozycji zmasakrowanego ciała, poddanego wymyślnym torturom i nieczytelnemu początkowo zbrodniczemu rytuałowi.

Tamże, s. 385 . 
Niewątpliwie Ziarno prawdy ${ }^{33}$ nie jest powieścią reprezentującą literaturę wysoką, najwyraźniej brakuje jej znamion finezji, skomplikowanej nadorganizacji formalnej. Słabości te jednak zostały zrównoważone przez umiejętność osadzenia w realiach współczesnej małomiasteczkowej Polski ważnego zagadnienia antropologicznego, obecnego w debatach publicznych ostatnich dekad - stosunku do Innego ${ }^{34}$, niechlubnych epizodów historycznych, naznaczonych przemocą wobec obcych. Nieoczekiwanie genologiczna klasyfikacja książki okazała się tu atutem; popularna powieść sensacyjna znajduje się wszakże na obrzeżach dominujących dyskursów publicznych na temat polskiego antysemityzmu, nie podlega zatem wpływom 'normatywnych poetyk', pozostawiając autorowi pole do eksperymentalnego wykorzystania konceptu „żydowskich widm”. Powieść Miłoszewskiego umiejętnie omija pułapki literackiej spektrologii; dzięki dominującej w niej stylistyce sarkastycznego racjonalizmu autorowi udało się uchylić tonację fałszywej wzniosłości, tak chętnie wykorzystywanej przez współczesną postmemorialną literaturę o Zagładzie.

Widmowość w znaczeniu Derridiańskim przyjmuje tu formę znaczeń, ujawniających się w przesuniętych płaszczyznach struktury tekstu literackiego. Powieść Miłoszewskiego, mimo pewnej przezroczystości narracji, ma interesującą, zawikłaną kompozycję, przypominającą nieco formę powieści szkatułkowej. Na różnych poziomach narracji powtarzają się tu podobne motywy, w swojej istocie spektralne. Są to motywy (domniemanych) duchów, a także frenetyczne obrazy krwi i „żywego mięsa”. Pojawiają się one w świecie przedstawionym powieści, we wspomnieniach i dokumentach archiwalnych, jak również w symbolicznej matrycy owych powtórzeń - słynnym obrazie Karola de Prevot w katedrze sandomierskiej, poświęconym „legendzie o krwi"35.

Duchem jest postać widoczna na nagraniu ulicznej kamery (to postać domniemanego mordercy), a także narrator mrocznych monologów, którego

Bardzo interesujący artykuł poświęcił twórczości Zygmunta Miłoszewskiego Przemysław Czapliński, odnajdując w niej projekt krytyki Polski postkomunistycznej. Zob. P. Czapliński Komisarz Szacki mówi dość, „Książki. Magazyn do czytania” 25.122014.

Zob. monografię Joanny Beaty Michlic Obcy jako zagrożenie. ObrazŻyda w Polsce od roku 1880 do czasów obecnych, Żydowski Instytut Historyczny, Warszawa 2015. cie pisania powieści - jest nim znana rozprawa antropologiczna Joanny Tokarskiej-Bakir Legendy o krwi. Antropologia przesq̨du, W.A.B., Warszawa 2008. 
tożsamość pozostaje przez dłuższy czas nieznana. Nie wiadomo, czy monologi te to retrospektywne przemyślenia żydowskiego lekarza Wajsbrota, czy też gorączkowe myśli mordercy, który sfingował swoją śmierć - w każdym razie w obydwu przypadkach narrator przemawiałby z pustki, ze świata umarłych lub z obszaru „fikcji mortualnej”, a zatem jego kondycja byłaby kondycją widma, upiora, głosu umarłego.

Wszystko kryją mogiły, a to, co zostało, jakieś bardzo jest dalekie i zawoalowane takimi uczuciami, których nie może pojąć. Taka siła żalu i zawziętości, taka żądza zniszczenia, po prostu chęć zemsty. Żeby zająć myśli, w kółko, do znudzenia, powtarza w głowie wszystkie elementy planu, wydaje się, że nie może być mowy o błędzie, ale strach nie jest przez to mniejszy, napięcie nie znika. Chce uciekać, ale plan nie przewiduje ucieczki, musi czekać. Potworne jest to czekanie, dźwięki są za głośne, światła za jasne, barwy za jaskrawe. Tykanie zegara na ścianie jest dokuczliwe niczym kuranty z ratusza, każda kolejna sekunda doprowadza go do pasji. ${ }^{36}$

„Tematy żydowskie” wyłaniają się w horyzoncie powieści już w pierwszych jej sekwencjach. Motyw żydowskiej zemsty, dokonanej na mieszkańcach „kościelnego miasta z antysemicką przeszłością” zostaje pieczołowicie zainscenizowany z udziałem tajemniczego chasyda („zjawy”, „przybysza zza grobu"), którego w miejscu zbrodni zarejestrowała kamera, a także charakterystycznego rekwizytu - noża „chalef”, używanego do rytualnego uboju bydła, wreszcie upozowanych zwłok i motywu krwi. Kolejne zbrodnie wydają się również zmodyfikowanym wariantem uboju rytualnego i związanych z nim antysemickich przesądów.

Poznawczą dominantą śledztwa staje się „etniczna” wykładnia przestępstwa, w myśl której seria okrutnych zbrodni byłaby przewrotną realizacją chrześcijańskiego zabobonu, „legendy o krwi” (przewrotną, bo dokonaną przez upiora - żydowskiego mściciela). Stopniowo wypiera ona racjonalne hipotezy prokuratorów, którzy trafnie wytypowali prawdziwego mordercę. Wiedza, „prawda” o zbrodni (a raczej jej najbardziej prawdopodobna hipoteza) zostaje wszakże podana na początku śledztwa, bohater (prokurator Szacki) jednak nie rozpoznaje jej, traci ją z pola widzenia, ponieważ pozwala 
się uwieść wykładni fałszywej - ulega sile antysemickiego mitu, mimo że w warstwie intelektualnej prowadzi z nim zażarty spór.

Derridiańskie zaszczepianie na sobie różnych wymiarów czasu przyjmuje tu ponurą, depresyjną postać. Wydaje się, że nie ma ucieczki przed sporem, jaki wiodą z sobą antysemicki performatyw i światły, oświeceniowy dyskurs. Dynamika tego sporu jest zdeterminowana przez zastany porządek symboliczny - w jego ramach stylizacja na 'legendę o krwi' nie jest jednym z wymiarów szkatułkowej opowieści, lecz złowieszczą matrycą widmowej 'mise en abyme'. Prokurator Szacki nie potrafi uchylić przysługującej jej mocy, może jedynie bezradnie przyglądać się skutkom sprawczej siły irracjonalnej narracji.

Motyw żydowskiej zemsty okazuje się zatem przemyślną inscenizacją, ale w jakim celu rozwijaną? Nadmiar symbolicznego, obfitość znaczeń naddanych odkłada się tu na podobieństwo fałd, przesłaniających gładką powierzchnię realności, odsuwających w czasie moment odsłonięcia "prawdy" (czyli wiedzy o tym, jak bardzo trywialne były motywy mordercy). Istotą spektralności okazuje się strategia mimikry, wymyślnej teatralności, nadpisanej nad teatrem życia społecznego, w którym każdy gra określone role. Szacki i Budnikowa uosabiają nowoczesność, nowoczesny racjonalizm i ideał tolerancji wobec Innego, Szyller - „oświecony” nacjonalizm i zarazem ekonomiczną, neoliberalną filozofię społeczną, przypadkowi mieszkańcy Sandomierza - przywiązanie do ksenofobicznych uprzedzeń. Widmowość - w znaczeniu, o którym była mowa w poprzednim podrozdziale - czyni widocznym ów układ ról, obnażając równocześnie ich kruchość i żywotność afektywnej natury etnicznych konstruktów tożsamości.

A gdzie podziały się żydowskie upiory, „, chasydzi”, tak sugestywnie zaznaczający swoją obecność w pierwszych rozdziałach powieści? Spektralność, rozpatrywana w kontekście żydowskiej śmierci, została najwyraźniej ulokowana na innych poziomach tekstu. W przewrotnej powieści Miłoszewskiego żydowski „duch” okazuje się realny, cielesny, irytujący, pozbawiony gustu i dobrych manier, wprawiający w zakłopotanie (okazuje się nim stary inspektor Leon Wilczur - syn doktora Wajsbrota). „Widmo” jest więc obecne od początku opowieści, towarzyszy głównemu bohaterowi niczym jego cień.

Wilczur wyczerpuje Derridiańską definicję widma - wyłamuje się z ram rzeczywistości jako postać ciemna, dziwna, niemal abjektalna; jest też postrzegany przez narratora jako personifikacja demonicznej negatywności („było w nim coś, co odrzucało”, jego wypowiedzi „były zawsze nacechowane negatywnie"), wreszcie jako postać, która gra tytułowym pojęciem „prawdy”, podważając wyznawany przez narratora porządek epistemologiczny. 
Jak by to panu wytłumaczyć... - Wilczur zamyślił się, przez co jego twarz nabrała upiornego, trupiego wyrazu. W mdłym świetle pizzerii, za zasłoną papierosowego dymu, wyglądał jak nieudolnie animowana mumia. - Ludzie znoszą go tylko dlatego, że Budnikowa go wybrała. Myślą, że trudno, niech sobie będzie oszołomiony, ale w sumie ma rację, a jeśli przy jego boku stoi taka kobieta, to nie może być zły.

Uwielbiał ją, ale było w tym uwielbieniu coś brudnego - sączył swój jad Wilczur - coś zaborczego, lepkiego, powiedziałbym. ${ }^{37}$

Związek Wilczura z figurą prawdy jest głęboki, istotowy. Tytuł powieści, aczkolwiek sarkastycznie wieloznaczny, podsuwa jednocześnie ważką sugestię, w myśl której prawda ma naturę ziarnistą, składa się z nieciągłych skupisk (materii? znaczeń? informacji?), jest punktowa, nierówna, ironicznie zakrzywiona. Przypomina zdemontowany przez dekonstrukcjonistów kartezjańsko-kantowski 'logos'38. W podobnych kategoriach i rejestrach estetycznych objawia się w powieści postać Wilczura - w jego opisie przeważają cechy, akcentujące nieforemność, niezborność, chropowatość, zgniecenie, jak gdyby nieustanne wypadanie z konwencji.

Najistotniejszy jednak poziom spektralności tworzą subteksty, nieuchronnie narzucające się w lekturze i osadzające morderstwa w konkretnym kontekście historycznym. Krążące w narracji obrazy krwi, zbezczeszczenia ciała, zdeformowanych, trudno rozpoznawalnych zwłok przywołują skojarzenia z mechanizmem przemocy pogromowej, z jej atawistycznym odruchem wrogości wobec obcych, okrucieństwem i ważną rolą podbudowy symbolicznej, która uruchamia gwałt. Istotną rolę w rekonstrukcji tej koncepcji interpretacyjnej pełnią również zbieżności topograficzne - kilkakrotnie pojawiają się tu znaczące wzmianki o Kielcach jako lokalnej metropolii, której odbiciem w mniejszej skali jest Sandomierz. Również gwałtowność zranień, stopień zdeformowania ciał przywodzą na myśl zdjęcia Julii Pirotte ukazujące ofiary pogromu kieleckiego. Relacja łącząca obydwie płaszczyzny wydarzeń - plan fikcyjnej opowieści kryminalnej i historycznej zbrodni, w której Polacy wystąpili w roli sprawców - wydaje się niejasna, zawikłana i wielokierunkowa. Można jednak zaryzykować hipotezę, że fikcyjna zbrodnia z powieści Miłoszewskiego jest dalekim odbiciem, 'powidokiem' strasznej przeszłości,

37 Z. Miłoszewski Ziarno prawdy, s. 46.

38 Por. A. Burzyńska Anty-teoria literatura, Universitas, Kraków 2006, s. 416. 
rzutowanym jako fantom na „ekran, który również okazuje się fantomatyczny" (wedle przytoczonej wcześniej formuły Derridy). Kompetencje przekazu historycznego przejmuje tu zwielokrotniona praca widma, która wytwarza efekt "prawdy" o wydarzeniach przez ich zniekształcające wysublimowanie i usytuowanie w wielu perspektywach czasowych.

W procesie tym wyjątkowo aktywną rolę odgrywa przestrzeń - poszczególne sekwencje fabularne są powiązane z ujawnianiem się kolejnych figur spacjalnych, obciążonych symbolicznym znaczeniem. Podziemia, korytarze, opuszczone budowle, ruiny, archiwum, cmentarz wydają się nie tylko elementami fikcyjnej topografii, ale także (aż nazbyt) czytelnymi figurami zbiorowej podświadomości i pamięci ${ }^{39}$. W owych opustoszałych miejscach zdeponowane zostały fragmentaryczne wspomnienia, rekwizyty o niejasnym przeznaczeniu, urwane w pół słowa opowieści o polsko-żydowskim sąsiedztwie. Eksplozja, wywołana przez mordercę, która najdosłowniej wstrząsnęła fundamentami Sandomierza powoduje symboliczne przesunięcie warstw zbiorowej niepamięci, zapoczątkowuje ruchy tektoniczne w obrębie pracy memorialnej, zdominowanej przez amnezję $\mathrm{i}$ judeofobiczne przesądy.

Miłoszewski w podobny sposób miesza porządki, narusza stabilne relacje i uporządkowania - czasami w sposób karkołomny, trudny do zaakceptowania. W powieściowym świecie przemieszczeniu ulegają relacje „ukrywający się - ścigający”, „sprawca - ofiara”, „powierzchnia - głębia”, „przesąd - dyskurs oświecony”, „prywatne - wspólnotowe”. Naruszone porządki zespalają się na powrót w gwałtownym afektywnym splocie, który potęguje ich moc oddziaływania, gdy wychodzi na jaw, że to Budnik - lokalny aktywista, walczący z ksenofobią - wymierza akt zemsty zarazem wiarołomnej żonie, jak i antysemickiej społeczności. Złączenie tych dwóch afektów, którego sens nie zostaje w powieści dokładnie objaśniony, wywołuje niejasną reakcję „wielkiej trwogi" (by posłużyć się tytułem książki Marcina Zaremby). Niezrozumiałe, przerażające wydają się źródła i motywacje niewyobrażalnych zbrodni, które tworzą widmowy łańcuch, Derridiańską serię miejsc i osób nawiedzanych przez „duchy”.

Por. A. Assmann Przestrzenie pamięci. Formy i przemiany pamięci kulturowej, przeł. P. Przybyła, w: Pamięć zbiorowa i kulturowa. Współczesna perspektywa niemiecka, red. M. Saryusz-Wolska, Universitas, Kraków 2009; E. Donato Ruiny pamięci: fragmenty archeologiczne i artefakty tekstowe, przeł. D. Gostyńska, „Pamiętnik Literacki" 1986 z. 3. 
Jak już wspomniałam, w Ziarnie prawdy motywy widm i nawiedzeń ustanawiają warstwę znaczeń pozornych, przesłaniających istotę rzeczy. "Prawdziwy trup" (rekwizyt z powieści kryminalnej) pojawia się niejako w zastępstwie, jako bezradna repetycja zbrodni pogromowej sprzed lat, maskująca niemożność przepracowania prawdy o towarzyszących jej okolicznościach i następstwach. Języki zastępcze, „prawdy” kompensacyjne (czyli wyszukane inscenizacje zbrodni) przesłaniają najbardziej dotkliwy wymiar upiorności - wiedzę o tym, że Żydzi do Sandomierza już nie wrócą, nawet jako fantomy, upiory. O szczególnej wartości powieści Miłoszewskiego w perspektywie dyskutowanej tu spektralności decyduje właściwy jej rys radykalnej deziluzji - historia o (żydowskich) upiorach to doświadczenie, przez które musi przejść czytelnik, by silnie odczuć wielkość utraty Innego i - co bardziej dotkliwe - utraty uspokajającej wiary w możliwość jej zrekompensowania.

\section{Ponadgatunkowe substytucje. Kości i ości Jonasza Sterna}

Derridiańska teoria spektralna, problematyzująca naturę widma, prowadzi do wniosku, że jest ono nie-antropomorficzne, ahistoryczne, nie-ludzkie , a zatem - postludzkie. Trafność tego rozpoznania potwierdza refleksja nad możliwością spektralnej analizy obrazów Jonasza Sterna, polsko-żydowskiego artysty, związanego z Grupą Krakowską, w którego twórczości motyw widmologiczny okazuje się spoiwem, łączącym biografię, dzieło sztuki, a także wpisany weń dyskurs metaartystyczny.

Stern okupację niemiecką spędził we Lwowie, na terenie lwowskiego getta. Okres ten dokumentuje cykl ekspresjonistycznych w formie linorytów poświęconych wyjątkowo traumatycznym wydarzeniom $\mathrm{z}$ historii gettowej społeczności (ja np. „polowanie na dzieci”). W czasie wczesnej akcji deportacyjnej artyście udało się zbiec z pociągu, który wiózł żydowskich mieszkańców Lwowa do obozu zagłady w Bełżcu. W końcowym okresie istnienia getta został jednak ponownie schwytany i doprowadzony do miejsca masowej egzekucji w wąwozie w Lasach Janowskich. Stern przeżył egzekucję - nagi wydostał się nocą spod sterty trupów i wyczołgał na pobliskie pole ${ }^{40}$.

40 O epizodzie 'wyjścia z grobu' i fenomenie 'traumy wskrzeszenia' wyczerpująco pisze Jacek Leociak, omawiając inne, analogiczne przypadki ocalenia. Zob. J. Leociak Wyjście z grobu, w: tegoż Doświadczenia graniczne. Studia o dwudziestowiecznych formach reprezentacji, Wydawnictwo IBL PAN, Warszawa 2009. 
Przetrwał wojnę, ukrywając się w domu ukraińskiej chłopki, następnie na Węgrzech pod przybranym nazwiskiem zmarłego przyjaciela ${ }^{41}$.

Wszystkie te okoliczności sprawiły, że Stern w całej powojennej twórczości musiał mierzyć się ze swoim własnym widmem, z niespełnionym wariantem swojego losu. Inaczej rzecz ujmując - sam Stern wydaje się niemal dosłownym wcieleniem widma, zmartwychwstałym, który zamieszkiwał obszar na pograniczu życia i śmierci. Obraz samego siebie jako umarłego towarzyszy artyście niczym „lepki” sobowtór, „obrysowujący” jego osobowość, a zarazem zaznaczający swoją wobec niej różnicę. Kondycja ta nie oznacza prostego podziału, rozczepienia jaźni między 'realną' osobę i jej lustrzane, fantomowe odbicie; raczej zapoczątkowuje proces trwałej niestabilności, utraty tożsamości homogenicznych, które odtąd będą nieustannie podważane, poddawane działaniom samokwestionującym. Stan ten przywodzi na myśl dylematy narratora Derridiańskiej Prawdy w malarstwie:

Czym jest 'moje widmo'? Co oznacza wyrażenie 'widmo mojego innego Ja'? Czy moje inne Ja jest mną samym, czy też innym Ja, innym, który mówi Ja? Czy też jest takim mną - które jest sobą jedynie podzielone za sprawą widma swojego sobowtóra? ${ }^{42}$

Poza paradokumentalnymi linorytami z lat 40., w których artysta posługuje się tradycyjną, figuratywną poetyką, trudno zrazu w jego dziele dopatrzeć się bezpośrednich nawiązań do wydarzenia granicznego, jakim były pobyt w getcie i upiorna, niedokonana egzekucja (możliwość takich odniesień sugerują jedynie tytuły niektórych obrazów lub cykli malarskich, np. Wyniszczenie, Dót czy jeden z ostatnich kolaży pt. Upokorzenie). W dojrzałej fazie twórczości Stern wypracował charakterystyczną, łatwo rozpoznawalną formułę malarstwa - od połowy lat 50. tworzył assemblages, w których na powierzchnię płótna naklejał "obce" elementy: zmięte tkaniny lub sieci, rybie i zwierzęce ości i kości, pióra, a także wyprawione skóry ryb (w późniejszym okresie również fotografie). Reliefy, powstałe przy zastosowaniu tej techniki

Zob. M. Zientara Holocaust Survivors. Artur Nacht-Smaborski, Erna Rosenstein, Jonasz Stern, Muzeum Historyczne Miasta Krakowa, Kraków 2012; A. Markowska Język Neuera. O twórczości Jonasza Sterna, Uniwersytet Śląski filia w Cieszynie, Cieszyn 1998; Kalendarium, w: Stulecie. Prace Jonasza Sterna (1904-1988) z lat 30.-80., Państwowa Galeria Sztuki, Sopot 2005. 
stały się zapisem osobliwego, trwającego latami procesu, polegającego na kolekcjonowaniu czy tworzeniu przejmującego archiwum resztek organicznych ${ }^{43}$. Jest to kolekcja na poły niezrozumiała, otoczona ramą pustki, bezcelowości, artysta wszakże pieczołowicie przechowuje to, co zazwyczaj zasługuje na usunięcie, zniszczenie.

Przedmioty doczepione do powierzchni płócien nie tylko rozbijają ich dwuwymiarowość, lecz także uderzają w samą ideę malarskiego przedstawienia, w rygory estetyczne, konstytuujące jego umowną realność. Jednak nie jest to jedynie awangardowy gest, dekonstruujący zastane konwencje reprezentacji ${ }^{44}$. Bowiem nie o przedstawienie Zagłady, nie o efekt mimetycznego jej odwzorowania tu idzie ${ }^{45}$. Sens artystycznej aktywności został pomyślany inaczej, bardziej radykalnie - celem Sterna jest raczej konstruowanie przy użyciu ości, kości, rybich skór kosmogonicznych map czy schematów rzeczywistości ${ }^{46}$. O takim zamyśle świadczą tytuły kompozycji, niezliczone „pejzaże”, „krajobrazy”, ,strefy”. Stern wywodzi swoją widmową kosmogonię z obrzeży świata organicznego, z obszaru, w którym dystynkcja żywe/martwe wyznacza punkt wahliwej opozycji. Podczas gdy człowiek witruwiański Leonarda da Vinci był modelem kosmosu ery optymistycznego humanizmu, Pejzaż I Sterna jest „odpadkowym” modelem wszechświata, skonstruowanym z perspektywy nicości, masowego grobu lub śmietnika. A widmo - jak powiada Derrida - zawsze pochodzi z ziemi, z czegoś „najgłębszego, upokarzanego, wilgotnego" ${ }^{47}$. Jest pogardzanym, nieprzyjemnym wariantem bytu, akceptowanym niechętnie, z poczuciem dyskomfortu.

43 Alicja Kuczyńska w artykule Pamięć poprzez sztukę poczyniła interesującą uwagę, pisząc, że charakterystycznym atrybutem artystycznych zapisów pamięci o Zagładzie jest wyeksponowanie funkcji magazynowania, które zastępuje imperatyw odtwarzania rzeczywistości. Zob. A. Kuczyńska Pamięć poprzez sztukę, w: Pamięć Shoah. Kulturowe reprezentacje i praktyki upamiętnienia, red. T. Majewski, A. Zeidler-Janiszewska, Officyna, Łódź 2009, s. 657.

44 Odmienną strategię uporczywego odtwarzania realistycznego, figuratywnego obrazu zmarłych rodziców stosowała Erna Rosenstein. Por. D. Jarecka Postać rodziców i zdjęcie znalezione w ziemi, w: D. Jarecka, B. Piwowarska Erna Rosenstein. Mogę powtarzać tylko nieświadomie/l can repeat only unconsciously, Fundacja Galerii Foksal, Warszawa 2014.

45 O niebezpieczeństwie fetyszyzacji i sublimacji obrazów z Zagłady zob. artykuł Anji Tippner Postkatastroficzne relikty i relikwie: los obrazów po Holokauście „ Poznańskie Studia Polonistyczne" Seria Literacka 25, 2015.

46 Warto wspomnieć, że motyw ryby i wędzidła ogrywa istotną rolę w Derridiańskiej interpretacji rysunków Adamiego. Zob. J. Derrida $+R$, w: tegoż Prawda w malarstwie.

47 J. Derrida Marx's Gespenster..., s. 133. 
Kości/ości okazują się uniwersalną substancją, skupiającą wielość znaczeń i użyć. Po pierwsze, mają one wyraźnie obecny wymiar abjektalny jako odpadki, resztki, które wywołują odczucia odrazy czy niesmaku. Niewątpliwie, można przypisać im sens mortualny - są one szczątkami istot umarłych, które nie zostały pogrzebane zgodnie z żałobnym rytuałem. Kontekst biografii Sterna przywołuje jeszcze jeden obszar znaczeń, związanych z postępowaniem śledczym, dowodowym, zakładającym eksplorację masowych grobów przez archeologów lub techników policyjnych ${ }^{48}$. Kości, szczątki organiczne, dzięki trwałości, względnej niepodatności na rozkład służą jako dowody w sprawie sądowej lub są badane jako relikty zaginionych cywilizacji. Postrzegane w tej perspektywie, przekraczają granicę nieludzkiego, stając się ważnym artefaktem, należącym do porządków symbolicznych ludzkiej cywilizacji.

Dlaczego jednak Stern używa ości/kości rybich, ptasich, zwierzęcych, a nie ludzkich? Czym motywowana jest ta ucieczka w stronę post/humanizmu? A może istniejąca w antropocentrycznej metafizyce ontologiczna przerwa, rozcięcie - typograficzny 'ukośnik' nie ma znaczenia w granicach wyobraźni malarskiej Sterna, nie zaznacza w niej żadnych istotnych dystynkcji?

Można przyjąć, że autor Znaków archaicznych, zastępując szczątki ludzkie zwierzęcymi i przekształcając je w wieloznaczne formy reprezentacji doświadczenia granicznego, praktykuje w swojej sztuce zasadę 'ponadgatunkowej substytucji'. Kości ptasie i rybie występują tu „w zastępstwie” $\mathrm{i}$ „w imieniu” szczątków ludzkich, reprezentują je, pozwalają zaistnieć w realności dzieła sztuki. Znosząc barierę między ludzkim i nieludzkim lub raczej, obnażając jej umowność i uwikłanie w struktury władzy, Stern używa kości zwierzęcych w funkcji „widm ludzkiego" i, szerzej, spektralnej alegorii, obejmującej wszystkie gatunki. Dzięki tej strategii kości i ości uzyskują walor uniwersalizmu, semiotyczności, zostają obdarzone swoistą poszerzoną podmiotowością.

Proces ten ma naturę spektralną, jego istotą jest bowiem rekonstrukcja braku, przywołanie fantomu świata umarłych i osadzenie go w materialności czasu teraźniejszego. Dynamikę przedstawienia w obrazach Sterna wyznaczają przejścia i transformacje, bowiem granice i podziały ustąpiły tu miejsca Latourowskim 'morfizmom'. Warto tu wspomnieć o tym, że słowo

48 Por. C. Study Colls O tym, co minęło, lecz nie zostało zapomniane: Badanie archeologiczne na terenie byłego obozu zagłady w Treblince, przeł. E. Felska, J. Giebułtowski, IFiS PAN, Warszawa 2012. 
'assemblage' używane jest nie tylko w historii sztuki, ale również w kręgu krytyki środowiskowej - Rosi Braidotti pisze m.in. o „złożeniach (assemblages) ludzkich i nieludzkich aktorów"49 , w podobnym porządku rozwija swoją teorię "splątania” bytów Bruno Latour ${ }^{50}$. W kompozycjach Sterna zwierzęce i rybie szczątki wchłaniają wspomnienia ludzkiej śmierci; to, co ludzkie, zespala się zaś ze swoim zwierzęcym analogonem. Dochodzi tu też do zatarcia antropocentrycznego rozumienia „widmowości”, które postrzegane było, jak pisze o tym Rosi Braidotti, jako negatywny odpowiednik ludzkiej podmiotowości, świadomości i postaw etycznych ${ }^{51}$. W Tablicach widmowość zyskuje walor pozytywności i sprawczości, 'roztapiając' w sobie antropocentryczne wyznaczniki dominacji człowieka nad bytami nieludzkimi.

Obszarem, w którym dokonują się wspomniane „geno-morfizmy”, staje się pismo. Kości i ości, doklejone do płaszczyzn obrazów, czasami ustanawiają układy chaotyczne, asemantyczne (jak w abstrakcyjnych kolażach z cyklu Eksterminacje z roku 1964), często jednak układają się w linie horyzontalne, tworzące uporządkowane, rytmiczne ciagi, przypominające tajemny zapis (Milczenie rodzajów z roku 1965). Jest to osobliwe prapismo, jak gdyby bardziej surowe i pierwotne niż piktogramy, a zarazem radykalizujące ideę leżącą u ich podstaw $^{52}$. „Litery” Sterna łączą bowiem dwa aspekty znaku, organicznie zespalając się z desygnatem, oznaczając znaczone w jednym błysku. Istotny wydaje się też ich status znaków wypukłych. Kość Sterna to rysa, litera czy dukt malarski, obdarzony nadmiarem, naddatkiem formy, to coś, co wystaje ponad powierzchnię i domaga się uwagi.

Powołanie do życia posthumanistycznego pisma wydaje się bardziej radykalnym gestem twórczym niż porzucenie figuratywności na rzecz abstrakcji. Z pewnego punktu widzenia moglibyśmy powiedzieć, że trójwymiarowa reliefowość płócien Sterna zastępuje renesansową perspektywę Masaccia, przeciwstawiając iluzji geometrycznego uporządkowania przestrzeni materialną porowatość, surowość praznaków, spokojną trwałość „tego, co pozostało". Pismo z kości staje się siatką sensu, narzuconą na spustoszony,

49 R. Braidotti Po człowieku, przeł. ). Bednarek, A. Kowalczyk, PWN, Warszawa 2014, s. 139.

50 B. Latour Splatajq̨c na nowo to, co społeczne. Wprowadzenie do teorii aktora-sieci, przeł. A. Derra, K. Abriszewski, Universitas, Kraków 2010. R. Braidotti Po człowieku, s. 65. Tablic Mojżeszowych", widząc w nich przekaz quasi-teologiczny. Zob. E. Jedlińska Sztuka po Holokauście, Biblioteka Tygla Kultury, Łódź 2001, s. 121. 
rozpadający się świat po katastrofie. Jest też „widmem widma”, postulowanym przez Derridę spektralnym zwielokrotnieniem, w którym to, co retrospektywne, przekształca się w wizję prospektywną. W tym kontekście technika, stosowana przez Sterna pozwala zinterpretować się jako strategia oporu przeciwko biowładzy, przeciwko uprawianej przez nią nekropolityce, której krańcowym przejawem była masowa śmierć w obozach zagłady. Pismo z odpadków okazuje się bardziej trwałe niż pamięć zniszczenia. Materializując spektralność, sprawia ono, że narracja o nawiedzeniu przez żydowskie widma przekształca się w przekaz o niezniszczalności życia (w znaczeniu ponadgatunkowym).

\section{Abstract}

\section{Aleksandra Ubertowska}

UNIVERSITY OF GDAŃSK

The Scratch, the Groove, the Imprint of (Not) Being There: Hauntology of the Holocaust

This article presents an attempt to analyse concepts from Jacques Derrida's hauntology and to apply those concepts as interpretive tools. Ubertowska uses them in her readings of post-traumatic literature, in particular texts and images that concern the Holocaust. In the analytical part of the interpretation Ubertowska focuses on motifs of bones and fishbones in Zygmunt Miłoszewski's popular novel Grain of Truth, but also in Jonasz Stern's paintings. The Cracow-based painter's methods are described as a spectral'substitution above and beyond genre'.

\section{Keywords}

spectre, hauntology, Holocaust, Jonasz Stern, Jacques Derrida 